DOI: https://doi.org/10.31933/jimt.v3i3

Received: 5 November 2021, Revised: 17 Desember 2021, Publish: 1 Februari 2022

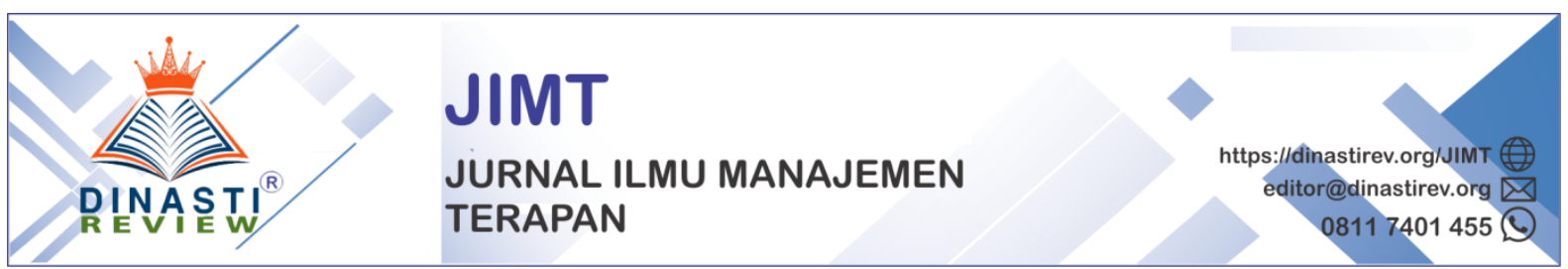

\title{
MODEL CITRA MEREK MELALUI KEPUASAN PELANGGAN BEAR BRAND: HARGA DAN KUALITAS PRODUK
}

\author{
Innes Hernikasari ${ }^{1}$, Hapzi $\mathrm{Ali}^{2}$, Hadita Hadita ${ }^{3}$ \\ ${ }^{1)}$ Mahasiswa Program Sarjana Manajemen, Universitas Bhayangkara Jakarta Raya, Indonesia, \\ email: inneshernikasari33@gmail.com \\ ${ }^{2)}$ Dosen Fakultas Ekonomi,Universitas Bhayangkara Jakarta Raya, Indonesia, email: \\ hapzi@dsn.ubharajaya.ac.id \\ ${ }^{3)}$ Dosen Fakultas Ekonomi, Universitas Bhayangkara Jakarta Raya, Indonesia, email: \\ hadita@dsn.ubharajaya.ac.id
}

Korespondensi Penulis: Innes Hernikasari ${ }^{1}$

\begin{abstract}
Abstrak: Penelitian ini digunakan untuk mengukur pengaruh persepsi harga dan kualitas produk terhadap citra merek melalui kepuasan pelanggan pada tahun 2021 di masa pandemi Covid-19 saat ini di Kelurahan wanasari. Penelitian ini merupakan penelitian kuantitatif dimana objek yang digunakan merupakan masyarakat atau konsumen yang sudah pernah mengkonsumsi produk Bear Brand di Kelurahan Wanasari. Penelitian ini dilakukan dengan teknik sampel Accidental sampling. Adapun jumlah sampel yang digunakan dalam penelitian ini adalah 252 responden. Rancangan yang digunakan dalam penelitian ini adalah pengujian hipotesis (hypothesis testing) dengan menggunakan teknik analisis structural equitation model (SEM) dengan alat bantu SmartPLS versi 3.0. Berdasarkan hasil penelitian ini menjelaskan bahwa; 1) Persepsi harga berpengaruh positif dan signifikan terhadap kepuasan pelaggan; 2) Persepsi harga berpengaruh positif dan signifikan terhadap citra merek; 3) Kualitas produk berpengaruh positif dan signifikan terhadap citra merek; 4) Kepuasan pelanggan berpengaruh positif dan signifikan terhadap citra merek; 5) Kepuasan pelanggan terbukti memediasi persepsi harga terhadap citra merek.; 6) Kepuasan pelanggan terbukti memediasi kualitas produk terhadap citra merek; 7) Kepuasan pelanggan terbukti memediasi kualitas produk terhadap citra merek.
\end{abstract}

Kata Kunci: Citra Merek, Kepuasan Pelanggan, Harga, dan Kualitas Produk

\section{PENDAHULUAN}

\section{Latar Belakang Masalah.}

Saat ini, banyak sekali bermunculan perusahaan yang bergerak dibidang manufaktur dan obat-obatan serta suplemen yang menawarkan produk-produk yang berhubungan dengan kesehatan. Hal ini disebabkan karena seluruh masyarakat khawatir dengan kesehatan tubuhnya dengan hal ini masayarakat indonesia mulai berfikir untuk kesehatan jangka panjang. Sehingga munculnya produk-produk kesehatan disambut baik oleh masyarakat karena masyarakat membutuhkan produk yang bisa mencegah tubuhnya dari berbagai macam penyakit serta dapat menjaga kekebalan tubuh. 
Salah satunya adalah Susu Bear Brand yang di produk dari PT. Nestle Indonesia merupakan perusahaan manufaktur yang memproduksi makanan dan minuman terbesar di dunia yang salah satu varian produknya (Bear Brand) bergerak dalam bidang produksi susu sterilisasi. Susu Bear Brand adalah susu sapi yang telah disterilkan yang mengandung kalori lengkap, sehingga cocok untuk dikonsumsi segala usia. Susu Bear Brand tetap diminati oleh masyarakat dibandingkan dengan susu kemasan merek lain.

Fenomena yang terjadi pada Bear Brand tak lepas dari kepuasan pelanggan yang cenderung terhadap persepsi masyarakat pada Bear Brand yang dimana para pandangan masyakat berasumsi bahwa kualitas Bear Brand dengan produk susu cair kemasan yang lain sedikit ada perbedaan namun dengan guna maanfaat nya yang sama. Namun yang menjadi permasalahnya adalah Bear Brand memiliki harga yang jauh lebih mahal dibandingkan dengan produk susu cair kemasan lainnya. Dengan permasalah ini akan mempengaruhi kepuasan pelanggan yang semakin mulai cenderung berkurang faktor banyak produk susu cair kemasan lain yang memiliki harga jauh lebih murah daripada susu Bear Brand.

Namun dengan kondisi saat PPKM ini Bear Brand sangat meningkat dan terpercaya dipandangan masyarakat dikarenakan masyakat mulai terpengaruh terhadap informasi terkait bahwa kualitas Bear Brand sangat bagus untuk kesehatan tubuh dibandingkan dengan produk susu cair kemasan lain oleh sebab itu harga Bear Brand jauh lebih mahal daripada produk susu cair kemasan lain dikarenakan kualitas produk Bear Brand jauh lebih unggul daripada produk susu cair kemasan lain. Dengan persepsi harga dan kualitas produk yang sangat mempengaruhi kepuasan pelanggan akan dapat meningkatkan niat beli ulang sehingga citra merek juga dapat berpengaruh dengan kepuasan pelanggan terhadap produk Bear Brand.

Banyaknya faktor yang dapat memiliki hubungan terhadap citra merek melalui kepuasan pelanggan dari beberapa penelitian terdahulu telah dilakukan guna mengetahui faktor-faktor apa saja yang memiliki hubungan terhadap variabel penelitian ini. Oleh karena itu, penulis termotivasi untuk melakukan penelitian tentang: "Pengaruh Persepsi Harga Dan Kualitas Produk Terhadap Citra Merek Melalui Kepuasan Pelanggan Bear Brand (Studi Pada Konsumen Di Kelurahan Wanasari)

\section{Identifikasi Masalah}

Berdasarkan latar belakang yang telah diuraikan diatas maka dapat diidentifikasikan masalah sebagai berikut:

1. Terjadi peningkatan top brand Bear Brand pada tahun 2021, namun tidak berdampak siginifikan terhadap citra merek, hal ini ditandai tidak terjadi peningkatan penjualan.

2. Terjadinya kenaikan harga Bear Brand dan ini berdampak pada citra merek dan kepuasan pelanggan .

3. Terjadinya persaingan harga dan kualitas produk dan ini berdampak kepada persepsi harga dan citra merek yang dijadikan salah satu alasan konsumen dalam memilih minuman susu cair kemasan.

\section{Rumusan Masalah}

Berdasarkan latar belakang, maka dapat di rumuskan permasalahan yang akan dibahas guna membangun hipotesis untuk riset selanjutnya yaitu:

1. Apakah persepsi harga berpengaruh terhadap kepuasan pelanggan?

2. Apakah kualitas produk berpengaruh terhadap kepuasan pelanggan?

3. Apakah persepsi harga berpengaruh terhadap citra merek ?

4. Apakah kualitas produk berpengaruh terhadap citra merek ?

5. Apakah kepuasan pelanggan berpengaruh terhadap citra merek ?

6. Apakah Apakah kepuasan pelanggan terbukti memediasi persepsi harga terhadap citra merek? 
7. Apakah Apakah kepuasan pelanggan terbukti memediasi persepsi harga terhadap citra merek?

\section{KAJIAN TEORI \\ Citra Merek}

Citra merek adalah persepsi konsumen terhadap merek sebagai refleksi dari asosiasi yang ada di pikiran atau benak konsumen (Kotler dan Keller, 2016). Namun, berdasarkan definisi citra merek, "citra merek (brand image) dapat dikatakan sebagai semacam asosiasi yang terjadi di benak konsumen ketika mereka mengingat merek tertentu. Asosiasi ini secara sederhana dapat terjadi dalam bentuk pemikiran dan citra tertentu yang terkait dengan suatu merek, dan ketika memikirkan orang lain”. (Sangadji dan sopiah 2013)

Sedangkan menurut Bayu Prawira Ni Nyoman Kerti (2013) citra merek adalah persepsi dan keyakinan akan banyaknya sekumpulan asosiasi merek yang datang pada pikiran setiap para konsumen.

Menurut Kotler \& Keller (2012) Indikator-indikator yang membentuk citra merek adalah: 1. Citra pembuat (Corporate Image), 2. Citra produk atau konsumen (Product Image), 3. Citra pemakai (User Image), Citra Merek sudah banyak di teliti oleh peneliti sebelumnya diantaranya adalah: (A. Y. Wydyanto, 2020), (Ali, Narulita, et al., 2018),(Setyowati, 2016),(Hazimi Bimaruci Hazrati Havidz, 2020),(Moh. Budi Darma, Sulaiman Effendi, 2018), (Agussalim M dan Hapzi Ali, 2017), (Ali \& Mappesona, 2016), (Ali, Narulita, et al., 2018), dan (Toto Handiman \& Ali, 2019), (Hadita, 2020),(Meutia et al., 2021)

\section{Kepuasan Pelanggan}

Kepuasan pelanggan adalah perbandingan kualitas layanan yang dialami pelanggan, yang diharapkan pelanggan apabila kualitas yang dialami oleh pelanggan lebih rendah yang diharapkan, maka akan terjadi ketidakpuasan yang dirasakan oleh pelanggan tidak sesuai dengan yang diharapkan, dan apabila kualitas pelayanan nya lebih yang diharapkan, maka pelanggan akan sangat puas (Andi Riyanto, 2018) Sedangkan menurut Tjiptono (2019) kepuasan pelanggan dapat diartikan sebagai perbandingan antara ekspektasi atau ekspektasi sebelum pembelian dengan persepsi kinerja pasca pembelian. Kesimpulan yang dapat ditarik dari definisi di atas adalah bahwa konsep pelanggan pada dasarnya adalah kepuasan, yang meliputi perbedaan antara harapan dan hasil kinerja yang dirasakan. Kepuasan pelanggan inilah yang menjadi dasar tercapainya pelanggan yang loyal atau setia Menurut Purnomo Edwin Setyo (2017) Indikator kepuasan pelanggan, yaitu: 1. Terpenuhinya harapan konsumen, 2. Merekomendasikan kepada pihak lain, 3. Kualitas layanan, 4. Loyal, 5. Lokasi.

Kepuasan Pelanggan sudah banyak di teliti oleh peneliti sebelumnya diantaranya adalah: (W. Wydyanto \& Rafqi Ilhamalimy, 2021),(Agussalim M dan Hapzi Ali, 2017),(Limakrisna \& Ali, 2016), (Sulistiorini \& Ali, 2017),(Rangga \& Nalendra, 2018), (Hadita, 2017),(Hadita, 2019)

\section{Persepsi Harga}

Persepsi Harga merupakan jumlah semua nilai yang diberikan oleh Konsumen digunakan untuk memperoleh keuntungan atas kepemilikan atau penggunaan suatu produk atau jasa. (Ari Setiyaningrum, Jusuf Udaya, 2015). Ada juga definisi persepsi harga yang menyatakan bahwa Persepsi Harga adalah sejumlah uang yang ditagihkan atas suatu produk dan jasa atau jumlah dari nilai yang ditukarkan Konsumen untuk dapat memperoleh manfaat dari menggunakan suatu produk dan jasa (Kotler \& Keller, 2016) Sedangkan Menurut Ruth Amryyanti \& dan Cahya (2013) mendefinisikan persepsi kewajaran harga sebagai penilaian bagi suatu hasil dan bagaimana suatu proses nantinya mendapatkan suatu hasil yang dapat diterima dan pastinya dalam suatu kewajaran dalam arti lain masuk akal. Indikator - indikator 
dari persepsi harga menurut Wifky Muharam dan Euis Soliha (2017) persepsi harga dapat diukur melalui beberapa indikator yang terdiri dari : 1. Daya Saing Harga, 2. Kesesuaian Harga Dengan Manfaat Harga, 3. Harga Sesuai Dengan Kualitas Produk

Persepsi Harga sudah banyak di teliti oleh peneliti sebelumnya diantaranya adalah: (Hazimi Bimaruci Hazrati Havidz, 2020),(Nastiti \& Astuti, 2019),(Suastini \& Mandala, 2018),(Arief Budiyanto, 2018),(Suarjana \& Suprapti, 2018), (Christina Catur Widayati et al., 2020), and (C.C. Widayati et al., 2020), (Ali, Narulita, et al., 2018), (Ikhsani \& Ali, 2017), (Richardo et al., 2020), (Brata et al., 2017), (R. Anggita \& Ali, 2017a), (Novansa \& Ali, 1926), (Meutia et al., 2021), (Hadita, 2019)

\section{Kualitas Produk}

Menurut Fandy Tjiptono (2015) definisi kualitas produk yaitu berfocus pada upaya pemenuhan kebutuhan dan keinginan konsumen serta ketepatan penyampaian untuk memenuhi harapan konsumen. Beberapa orang ada yang mendefinisikan kualitas produk adalah kemampuan suatu produk untuk memberikan hasil/kinerja yang sesuai atau melebihi dari apa yang diinginkan konsumen. Segala sesuatu yang dapat ditawarkan ke pasar untuk memenuhi atau melampaui harapan konsumen. Serta yang dapat ditawarkan ke pasar untuk diperhatikan, dibeli, digunakan dan dikonsumsi untuk memenuhi keinginan dan kebutuhan.(Kotler dan Keller, 2012) Menurut Sangadji dan Sopiah (2013) menjelaskan terdapat enam elemen kualitas produk, yaitu : 1. Kinerja, 2. Keandalan (Reliability), 3. Tampilan (Fitur),4. Daya Tahan (durability), 5. Kesesuaian dengan spesifikasi (Conformance of specifications), 6. Desain Kualitas Produk sudah banyak di teliti oleh peneliti sebelumnya diantaranya adalah: (Anggita\&Ali, 2017), (Ilhamalimy \& Mahaputra, 2021), (Imron, 2019) ,(Rispita dan Khasanah, 2019), (Agussalim M dan Hapzi Ali, 2017), (Ali, Narulita, et al., 2018), (Agussalim M dan Hapzi Ali, 2017), (Prihartono \& Ali, 2020),(Hadita et al., 2020)

\section{Penelitian Terdahulu}

Penelitian ini sebagaimana peneliti uraikan secara singkat hasil penelitian terdahulu yang relevan berkaitan dengan pengaruh harga dan kualitas produk terhadap citra merek melalui kepuasan pelanggan. Serta mencoba memahami hasil-hasil penelitian yang dilakukan oleh para penelliti sebelumnya. Berikut bahan rujukan sebagai acuan untuk penelitian:

Tabel 1. Penelitian terdahulu

\begin{tabular}{|c|l|l|l|l|}
\hline No & $\begin{array}{c}\text { Author, } \\
\text { Tahun dan } \\
\text { Judul }\end{array}$ & \multicolumn{1}{|c|}{ Hasil Penelitian } & $\begin{array}{l}\text { Persamaan Dengan } \\
\text { Penelitian }\end{array}$ & $\begin{array}{c}\text { Perbedaan Dengan } \\
\text { Penelitian }\end{array}$ \\
\hline $\mathbf{1}$ & $\mathbf{2}$ & \multicolumn{1}{|c|}{$\mathbf{3}$} & \multicolumn{1}{c|}{$\mathbf{4}$} & \multicolumn{1}{|c|}{$\mathbf{5}$} \\
\hline 1 & (Shihab, & $\begin{array}{l}\text { Hasil penelitian menunjukkan bahwa } \\
\text { variabel persepsi harga, kualitas } \\
\text { produk, citra merek dan layanan } \\
\text { purna jual secara parsial dan } \\
\text { simultan memiliki pengaruh yang } \\
\text { signifikan dan positif terhadap } \\
\text { keputusan pembelian. }\end{array}$ & $\begin{array}{l}\text { Terdapat persamaan } \\
\text { Bahwa penelitian } \\
\text { dan penulisan } \\
\text { memiliki persamaan } \\
\text { dalam meneliti } \\
\text { persepsi harga, } \\
\text { kualitas produk dan } \\
\text { citra merek terhadap } \\
\text { kepuasan konsumen }\end{array}$ & $\begin{array}{l}\text { Terdapat perbedaan } \\
\text { judul yang diteliti } \\
\text { oleh penulis variabel } \\
\text { layanan purna jual } \\
\text { terhadap keputusan } \\
\text { pembelian dan } \\
\text { dampaknya terkait } \\
\text { perusahan } \\
\text { elektronik. }\end{array}$ \\
\hline 2 & (Hartadi, & $\begin{array}{l}\text { Hasil penelitian menunjukkan } \\
\text { bahwa persepsi harga, kualitas } \\
\text { produk dan citra merek memiliki } \\
\text { pengaruh terhadap kepuasan } \\
\text { pelanggan secara parsial dan } \\
\text { simultan. Kualitas produk yang } \\
\text { mempunyai pengaruh dominan }\end{array}$ & $\begin{array}{l}\text { Terdapat persamaan } \\
\text { Bahwa memiliki } \\
\text { persamaan dalam } \\
\text { penelitian variabel } \\
\text { persepsi harga, } \\
\text { kualitas produk dan } \\
\text { citra merek terhadap }\end{array}$ & $\begin{array}{l}\text { Terdapat perbedaan } \\
\text { terkait variabel citra } \\
\text { merek sebagai } \\
\text { variabel tidak terikat } \\
\text { dan tidak terdapat } \\
\text { variabel intervening. }\end{array}$ \\
\hline
\end{tabular}




\begin{tabular}{|c|c|c|c|c|}
\hline & & terhadap kepuasan konsumen. & kepuasan pelanggan & \\
\hline 3 & $\begin{array}{l}\text { (Setyo, } \\
2017)\end{array}$ & $\begin{array}{l}\text { Hasil penelitian menunjukkan bahwa } \\
\text { variabel kualitas produk dan harga } \\
\text { berpengaruh secara simultan } \\
\text { terhadap kepuasan konsumen "Best } \\
\text { Autoworks". Variabel kualitas } \\
\text { produk berpengaruh secara parsial } \\
\text { namun harga tidak berpengaruh } \\
\text { secara parsial terhadap kepuasan } \\
\text { konsumen "Best Autoworks" }\end{array}$ & $\begin{array}{l}\text { Terdapat persamaan } \\
\text { Bahwa penelitian } \\
\text { dan penulis memiliki } \\
\text { persamaan dengan } \\
\text { variabel penelitian } \\
\text { yaitu kualitas produk } \\
\text {,harga dan kepuasan } \\
\text { konsumen }\end{array}$ & $\begin{array}{l}\text { Terdapat perbedaan } \\
\text { Bahwa variabel } \\
\text { peneliti tidak } \\
\text { terdapat variabel } \\
\text { intervening } \\
\text { (mediasi) }\end{array}$ \\
\hline 4 & $\begin{array}{l}\text { (Afnina \& } \\
\text { Hastuti, } \\
\text { 2018) }\end{array}$ & $\begin{array}{l}\text { Hasil penelitian dapat disimpulkan } \\
\text { bahwakualitas produk berpengaruh } \\
\text { positif terhadap kepuasan pelanggan }\end{array}$ & $\begin{array}{l}\text { Terdapat persamaan } \\
\text { Bahwa penelitian } \\
\text { dan penulisan } \\
\text { memiliki persamaan } \\
\text { dalam meneliti } \\
\text { tentang kualitas } \\
\text { produk,dan } \\
\text { kepuasaan pelanggan }\end{array}$ & $\begin{array}{l}\text { Peneliti tidak } \\
\text { menggunakan } \\
\text { variabel harga dan } \\
\text { citra merek sebagai } \\
\text { variabel intervening } \\
\text { atau variabel } \\
\text { mediasi }\end{array}$ \\
\hline 5 & $\begin{array}{l}\text { (Nugraha, } \\
2017 \text { ) }\end{array}$ & $\begin{array}{l}\text { Hasil penelitian menunjukkan bahwa } \\
\text { persepsi harga dan kualitas } \\
\text { pelayanan berpengaruh positif } \\
\text { terhadap citra merek dalam } \\
\text { meningkatkan minat menggunakan. } \\
\text { Variabel paling dominan dalam } \\
\text { mempengaruhi minat menggunakan } \\
\text { dengan mediasi citra merek } \\
\text { merupakan persepsi harga dan } \\
\text { kualitas layanan }\end{array}$ & $\begin{array}{l}\text { Terdapat persamaan } \\
\text { Bahwa penelitian } \\
\text { dan penulisan } \\
\text { memiliki persamaan } \\
\text { dalam meneliti } \\
\text { tentang persepsi } \\
\text { harga terhadap citra } \\
\text { merek }\end{array}$ & $\begin{array}{l}\text { Peneliti memiliki } \\
\text { perbedaan variabel } \\
\text { tidak terikat yaitu } \\
\text { kualitas pelayanan } \\
\text { dan variabel } \\
\text { intervening yang } \\
\text { berkaitan dengan } \\
\text { meningkatkan minat } \\
\text { penggunaan } \\
\text { perusahaan jasa } \\
\text { transportasi }\end{array}$ \\
\hline 6 & & $\begin{array}{l}\text { Hasil analisis menunjukkan bahwa } \\
\text { kualitas produk, persepsi harga, dan } \\
\text { memiliki pengaruh positif dan } \\
\text { signifikan terhadap citra merek dan } \\
\text { minat beli serta pengaruhnya } \\
\text { terhadap keputusan pembelian kartu } \\
\text { XL Axiata di Semarang }\end{array}$ & $\begin{array}{l}\text { Terdapat persamaan } \\
\text { bahwa penelitian dan } \\
\text { penulisan memiliki } \\
\text { persamaan dalam } \\
\text { meneliti tentang } \\
\text { kualitas } \\
\text { produk,persepsi } \\
\text { harga terhadap citra } \\
\text { merek }\end{array}$ & $\begin{array}{l}\text { Penelitian memiliki } \\
\text { variabel promosi dan } \\
\text { variabel intervening } \\
\text { minat beli serta } \\
\text { dampaknya pada } \\
\text { keputusan } \\
\text { pembelian }\end{array}$ \\
\hline 7 & $\begin{array}{l}\text { (Septeri, } \\
\text { 2018) }\end{array}$ & $\begin{array}{l}\text { Hasil penelitian menunjukkan bahwa } \\
\text { secara simultan kualitas produk dan } \\
\text { harga berpengaruh signifikan } \\
\text { terhadap citra }\end{array}$ & $\begin{array}{l}\text { Terdapat persamaan } \\
\text { Bahwa penelitian } \\
\text { dan penulisan } \\
\text { memiliki persamaan } \\
\text { dalam meneliti } \\
\text { kualitas produk dan } \\
\text { citra merek dan } \\
\text { kepuasan pelanggan }\end{array}$ & $\begin{array}{l}\text { Penelitian memiliki } \\
\text { variabel keputusan } \\
\text { pembelian }\end{array}$ \\
\hline 8 & $\begin{array}{l}\text { (Agussalim } \\
\text { M dan Hapzi } \\
\text { Ali, 2017) }\end{array}$ & $\begin{array}{l}\text { Hasil penelitian menunjukkan } \\
\text { kualitas produkdan kualitas } \\
\text { layanansecara parsial dan simultan } \\
\text { berpengaruh positif dan signifikan } \\
\text { terhadap citra merek dan kepuasan } \\
\text { pelangganpada Giant Raya } \\
\text { Tanggerang }\end{array}$ & $\begin{array}{l}\text { Terdapat persamaan } \\
\text { Bahwa penelitian } \\
\text { dan penulisan } \\
\text { memiliki persamaan } \\
\text { dalam meneliti } \\
\text { kualitas produk } \\
\text { terhadap citra merek } \\
\text { dan kepuasan } \\
\text { pelanggan }\end{array}$ & $\begin{array}{l}\text { Penelitian memiliki } \\
\text { variabel kualitas } \\
\text { layanan }\end{array}$ \\
\hline
\end{tabular}




\begin{tabular}{|c|c|c|c|c|}
\hline 9 & (Mira, 2018) & $\begin{array}{l}\text { Hasil penelitian ini menunjukkan } \\
\text { bahwa Citra Merek dan kualitas } \\
\text { pelayanan berpengaruh positif } \\
\text { terhadap kepuasan nasabah }\end{array}$ & $\begin{array}{l}\text { Terdapat persamaan } \\
\text { Bahwa penelitian } \\
\text { dan penulisan } \\
\text { memiliki persamaan } \\
\text { dalam meneliti citra } \\
\text { merek terhadap } \\
\text { kepuasan pelanggan }\end{array}$ & $\begin{array}{l}\text { Penelitian memiliki } \\
\text { variabel kualitas } \\
\text { pelayanan dan tidak } \\
\text { memiiki variabel } \\
\text { intervening }\end{array}$ \\
\hline 10 & $\begin{array}{l}\text { (W et al., } \\
2018 \text { ) }\end{array}$ & $\begin{array}{l}\text { Hasil penelitian ini menunjukkan } \\
\text { bahwa Citra Merek secara parsial } \\
\text { memiliki pengaruh yang tidak } \\
\text { signifikan terhadap Kepuasan } \\
\text { Pelanggan, variabel kualitas layanan } \\
\text { dan harga berpengaruh positif } \\
\text { terhadap kepuasan konsumen }\end{array}$ & $\begin{array}{l}\text { Terdapat persamaan } \\
\text { Bahwa penelitian } \\
\text { dan penulisan } \\
\text { memiliki persamaan } \\
\text { dalam meneliti citra } \\
\text { merek dan harga } \\
\text { terhadap kepuasan } \\
\text { pelanggan }\end{array}$ & $\begin{array}{l}\text { Penelitian memiliki } \\
\text { variabel kualitas } \\
\text { pelayanan dan } \\
\text { penelitian dalam } \\
\text { penulisan tidak } \\
\text { memiliki variabel } \\
\text { invening atau } \\
\text { variabel mediasi }\end{array}$ \\
\hline 11 & $\begin{array}{l}\text { (Pardede et } \\
\text { al., 2016) }\end{array}$ & $\begin{array}{l}\text { Hasil penelitian ini menunjukan } \\
\text { bahwa kepuasan konsumen } \\
\text { mempunyai pengaruh terhadap } \\
\text { keputusan pembelian yang } \\
\text { memediasi persepsi harga dan } \\
\text { kualitas produk }\end{array}$ & $\begin{array}{l}\text { Terdapat persamaan } \\
\text { Bahwa penelitian } \\
\text { dan penulisan } \\
\text { memiliki persamaan } \\
\text { dalam meneliti } \\
\text { variabel persepsi } \\
\text { harga dan kualitas } \\
\text { produk yang } \\
\text { dimediasi kepuasan } \\
\text { konsumen sebagai } \\
\text { variabel intervening }\end{array}$ & $\begin{array}{l}\text { Penelitian memiliki } \\
\text { variabel keputusan } \\
\text { pembelian yang } \\
\text { dimediasi oleh } \\
\text { variabel kepuasan } \\
\text { pelanggan }\end{array}$ \\
\hline 12 & (Seka, 2020) & $\begin{array}{l}\text { Hasil penelitian menunjukkan citra } \\
\text { merek dan kepercayaan merek } \\
\text { berpengaruh positif dan signifikan } \\
\text { terhadap loyalitas pelanggan melalui } \\
\text { kepuasan pelanggan }\end{array}$ & $\begin{array}{l}\text { Terdapat persamaan } \\
\text { Bahwa penelitian } \\
\text { dan penulisan } \\
\text { memiliki persamaan } \\
\text { dalam meneliti } \\
\text { variabel kepuasan } \\
\text { pelanggan sebagai } \\
\text { mediasi terhadap } \\
\text { ciyra merek }\end{array}$ & $\begin{array}{l}\text { Penelitian memiliki } \\
\text { variabel } \\
\text { kepercayaan merek } \\
\text { dan terdapat } \\
\text { pengaruh terhadap } \\
\text { loyalitas }\end{array}$ \\
\hline 13 & $\begin{array}{l}\text { (Wijaya \& } \\
\text { Nurcaya, } \\
\text { 2017) }\end{array}$ & $\begin{array}{l}\text { Hasil penelitian ini kualitas produk } \\
\text { memiliki pengaruh positif dan } \\
\text { signifikan terhadap kepuasan } \\
\text { pelanggan dan loyalitas merek, } \\
\text { pengaruh kewajaran harga terhadap } \\
\text { kepuasan pelanggan dan loyalitas } \\
\text { merek memiliki pengaruh yang } \\
\text { positif dan signifikan, serta terdapat } \\
\text { pengaruh positif dan signifikan } \\
\text { antara kepuasan pelanggan terhadap } \\
\text { loyalitas merek. }\end{array}$ & $\begin{array}{l}\text { Terdapat persamaan } \\
\text { Bahwa penelitian } \\
\text { dan penulisan } \\
\text { memiliki persamaan } \\
\text { dalam meneliti } \\
\text { variabel kualitas } \\
\text { produk dan kepuasan } \\
\text { konsumen sebagai } \\
\text { variabel terikat }\end{array}$ & $\begin{array}{l}\text { Penelitian memiliki } \\
\text { variabel intervening } \\
\text { kepuasan pelanggan } \\
\text { dan variabel } \\
\text { loyalitas merek } \\
\text { sebagai variabel } \\
\text { terikat }\end{array}$ \\
\hline 14 & $\begin{array}{l}\text { (Desti Putri } \\
\text { Rejeki, } \\
\text { 2019) }\end{array}$ & $\begin{array}{l}\text { Hasil penelitian Kepuasan pelanggan } \\
\text { berpengaruh secara signifikan } \\
\text { terhadap loyalitas pelanggan. } \\
\text { Kepuasan pelanggan memediasi } \\
\text { pengaruh kualitas produk terhadap } \\
\text { loyalitas pelanggan OPPO } \\
\text { Smartphone di Kota Malang. } \\
\text { Kepuasan pelanggan memediasi } \\
\text { pengaruh citra merek terhadap } \\
\text { loyalitas pelanggan pada pelanggan } \\
\text { OPPO Smartphone di Kota Malang. }\end{array}$ & $\begin{array}{l}\text { Terdapat persamaan } \\
\text { Bahwa penelitian } \\
\text { dan penulisan } \\
\text { memiliki persamaan } \\
\text { dalam meneliti } \\
\text { variabel kualitas } \\
\text { produk dan citra } \\
\text { merek melalui } \\
\text { kepuasan pelanggan }\end{array}$ & $\begin{array}{l}\text { Penelitian memiliki } \\
\text { variabel intervening } \\
\text { kepuasan pelanggan } \\
\text { dan variabel } \\
\text { loyalitas merek } \\
\text { sebagai variabel } \\
\text { terikat }\end{array}$ \\
\hline
\end{tabular}




\section{Kerangka pemikiran}

Berdasarkan rumusan masalah, tujuan Penelitian, kajian teori, penelitia terdahulu dan hubungan antar variabel maka kerangka berfikir riset ini adalah sebagai berikut:

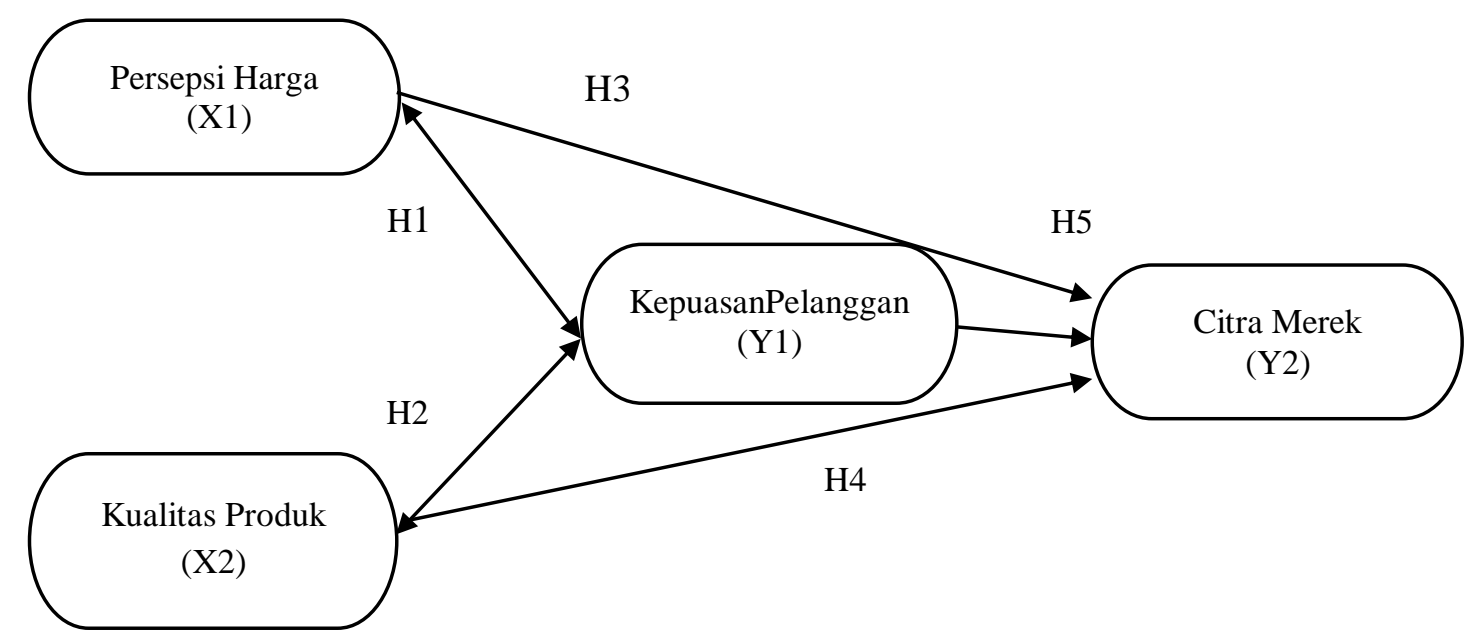

Gambar 1. Kerangka Pemikiran

\section{Hipotesis Penelitian}

$\mathbf{H}_{\mathbf{1}}=$ Persepsi Harga Berpengaruh Positif dan Signifikan Terhadap Kepuasan Pelanggan

$\mathbf{H}_{2}=$ Kualitas Produk Berpengaruh Positif dan Signifikan Terhadap Kepuasan Pelanggan

$\mathbf{H}_{\mathbf{3}}=$ Persepsi Harga Berpengaruh Positif dan Signifikan Terhadap Citra Merek

$\mathbf{H}_{\mathbf{4}}=$ Kualitas Produk Berpengaruh Positif dan Signifikan Terhadap Citra Merek

$\mathbf{H}_{5}=$ Kepuasan Pelanggan Berpengaruh Positif dan Signifikan Terhadap Citra Merek

$\mathbf{H}_{\mathbf{6}}=$ Kepuasan Pelanggan Terbukti Memediasi Persepsi Harga Terhadap Citra Merek Secara Signifikan

$\mathbf{H}_{7}=$ Kepuasan Pelanggan Terbukti Memediasi Kualitas Produk Terhadap Citra Merek Secara Signifikan

\section{METODE PENULISAN}

Metode penulisan artikel ilmiah ini adalah dengan metode kuantitatif dan kajian pustaka (Library Research). Mengkaji teori dan hubungan atau pengaruh antar variabel dari buku-buku dan jurnal baik secara off line di perpustakaan dan secara online yang bersumber dari Mendeley, Scholar Google dan media online lainnya. Dalam penelitian kuantitatif, kajian pustaka harus digunakan secara konsisten dengan asumsi-asumsi metodologis. Artinya harus digunakan secara induktif sehingga tidak mengarahkan pertanyaan-pertanyaan yang diajukan oleh peneliti. Salah satu alasan utama untuk melakukan penelitian kuantitatif yaitu bahwa penelitian tersebut bersifat menggambarkan atau menganalisis data. Digunakan untuk mengklasifikasikan data dalam bentuk angka dengan melakukan beberapa uji coba dengan pengumpulan data yang dilakukan yaitu dengan menggunakan kuesioner. (sugiyono, 2014)

Penelitian ini dilakukan dengan menggunakan model analisis jalur (path analiysis) dan teknik analisis Structural Equation Model (SEM) berbasis Partial Least Square (PLS).yang dibantu dengan aplikasi SMARTPLS 3.0 untuk menguji hipotesis. Karena diantara variabel eksogen dengan variabel endogen terdapat variabel intervening yang mempengaruhi. Penelitian ini dilakukan terhadap konsumen yang pernah mengkonsumsi produk susu Bear Brand di Kelurahan Wanasari dengan melakukan mengisi kuesioner melalui google form. Dalam penelitian menggunakan sampel accidental sampling sebanyak 
252 responden konsumen mengkonsumsi Bear Brand di Kelurahan Wanasari. Instrument penelitian dalam penelitian ini yaitu uji validitas dan reliabilitas yang digunakan metode uji Outer Model (Model Pengukuran) dan Inner Model (Model Struktural) yang berdasarkan dengan SEMPLS. Teknik analisis data berupa hasil analisis deskriptif dan analisis path. Dan uji hipotesis yaitu: pengaruh secara langsung dan tidak langsung.

\section{HASIL DAN PEMBAHASAN \\ Uji Validitas dan Reliabilitas}

Uji validitas adalah keadaan yang menggambarkan tingkat instrume yang bersangkutan mampu mengukur apa yang akan diukur (Arikunto, 2013: 167). Hasil penelitian yang valid bila terdapat kesamaan antara data yang terkumpul dengan data yang sesungguhnya terjadi pada obyek yang diteliti (Sugiyono, 2015: 172). Uji reliabilitas menunjukkan pada suatu pengertian bahwa suatu instrumen cukup dapat dipercaya untuk dapat digunakan sebagai alat pengumpul data karena instrumen tersebut sudah baik (Arikunto, 2013:221).

Berikut ini hasil uji validitas dan reliabilitas dalam penelitian ini dapat disajikan pada Tabel 2. berikut:

Tabel 2. Outer Model (Cross Loading Validity Deskriminan )

\begin{tabular}{|c|c|c|c|c|c|c|c|}
\hline \multirow{2}{*}{ Indikator } & \multicolumn{4}{|c|}{ Variabel } & \multirow{2}{*}{$\begin{array}{c}\text { Validitas } \\
\text { Keteran } \\
\text { gan }\end{array}$} & \multicolumn{2}{|c|}{ Reabilitas } \\
\hline & $\begin{array}{c}\text { Persepsi } \\
\text { Harga }\end{array}$ & $\begin{array}{c}\text { Kualitas } \\
\text { Produk }\end{array}$ & $\begin{array}{l}\text { Kepuasan } \\
\text { Pelanggan }\end{array}$ & $\begin{array}{c}\text { Citra } \\
\text { Merek }\end{array}$ & & $\begin{array}{l}\text { Composite } \\
\text { Reliability }\end{array}$ & Keterangan \\
\hline X1.3 & 0.732 & 0.553 & 0.489 & 0.487 & Valid & \multirow{5}{*}{0.803} & \multirow{5}{*}{$\begin{array}{c}\text { Reliabilitas } \\
\text { Tinggi }\end{array}$} \\
\hline X1.4 & 0.744 & 0.560 & 0.567 & 0.495 & Valid & & \\
\hline X1.5 & 0.733 & 0.498 & 0.579 & 0.538 & Valid & & \\
\hline X1.6 & 0.752 & 0.544 & 0.579 & 0.548 & Valid & & \\
\hline X1.7 & 0.778 & 0.526 & 0.535 & 0.513 & Valid & & \\
\hline X2.1 & 0.529 & 0.771 & 0.632 & 0.562 & Valid & \multirow{7}{*}{0.859} & \multirow{7}{*}{$\begin{array}{c}\text { Reabilitas } \\
\text { Tinggi }\end{array}$} \\
\hline $\mathrm{X} 2.3$ & 0.526 & 0.736 & 0.545 & 0.446 & Valid & & \\
\hline $\mathrm{X} 2.5$ & 0.595 & 0.700 & 0.571 & 0.595 & Valid & & \\
\hline $\mathrm{X} 2.7$ & 0.486 & 0.742 & 0.595 & 0.504 & Valid & & \\
\hline X2.9 & 0.507 & 0.762 & 0.622 & 0.561 & Valid & & \\
\hline X2.10 & 0431 & 0.704 & 0.553 & 0.462 & Valid & & \\
\hline X2.13 & 0.616 & 0.737 & 0.566 & 0.480 & Valid & & \\
\hline Y1.1 & 0.480 & 0.561 & 0.719 & 0.559 & Valid & \multirow{7}{*}{0.873} & \multirow{7}{*}{$\begin{array}{c}\text { Reabilitas } \\
\text { Tinggi }\end{array}$} \\
\hline Y1.2 & 0.568 & 0.625 & 0.742 & 0.597 & Valid & & \\
\hline Y1.3 & 0525 & 0.519 & 0.755 & 0.553 & Valid & & \\
\hline Y1.4 & 0.554 & 0.584 & 0.770 & 0.609 & Valid & & \\
\hline Y1.5 & 0.573 & 0.608 & 0.798 & 0.639 & Valid & & \\
\hline Y1.6 & 0.593 & 0.641 & 0.712 & 0.514 & Valid & & \\
\hline Y1.7 & 0.589 & 0.642 & 0.777 & 0.653 & Valid & & \\
\hline Y2.1 & 0.509 & 0.539 & 0.601 & 0.742 & Valid & \multirow{5}{*}{0.853} & \multirow{5}{*}{$\begin{array}{l}\text { Reabilitas } \\
\text { Tinggi }\end{array}$} \\
\hline Y2.2 & 0.533 & 0.547 & 0.635 & 0.825 & Valid & & \\
\hline Y2.4 & 0.518 & 0.543 & 0.592 & 0.777 & Valid & & \\
\hline Y2.5 & 0.591 & 0.569 & 0.682 & 0.807 & Valid & & \\
\hline Y2.6 & 0.590 & 0.597 & 0.594 & 0.814 & Valid & & \\
\hline
\end{tabular}

Berdasarkan pada tabel diatas yang menunjukkan hasil nilai Cross Loading, dapat diketahui bahwa masing-masing item indikator telah memiliki nilai cross loading yang besar dibandingkan dengan item indikator pada variabel lainnya. Seperti pada Persepsi Harga telah 
memiliki nilai cross loading lebih besar dibandingkan dengan nilai cross loading pada Variabel Kualitas Harga, Kepuasan Pelanggan dan Citra Merek. Maka, hasil dari pengujian ini dinyatakan valid secara diskriminan. Namun berdasarkan di tabel diatas menujukan bahwa variabel Persepsi Harga, Kualitas Produk, Citra Merek dan Kepuasan Pelanggan memiliki hasil nilai yang dapat dinyatakan bahwa reabilitas tinggi

\section{Evaluasi Model Struktural (Inner Model)}

Evaluasi model struktural pada SEM dengan PLS dilakukan dengan melakukan uji Rsquared $\left(\mathrm{R}^{2}\right)$ dan uji $\mathrm{Q}-$ Square $\left(\mathrm{Q}^{2)}\right.$ melalui estimasi koefisien jalur.

\section{Uji R-Square ( $\left.\mathbf{R}^{2}\right)$}

Pada Penelitian ini, tahap selanjutnya untuk analisis untuk menilai adanya seberapa besaran konstruk endogen atau variabel Y dapat mempresentasikan atau dapat dijelaskan oleh variabel eksogen atau variabel $\mathrm{X}$ dari hasil pengujian yang telah diujikan. Hal ini dilakukan pada tahap Uji R-Square atau $\mathrm{R}^{2}$. Jika $\mathrm{R}$ Square $\left(\mathrm{R}^{2}\right)$ sebesar 0,67 menunjukan model kuat, sebesar 0,33 bahwa model moderate dan sebesar 0,19 bahwa model dikatagorikan lemah (Ghozali, 2015)

Pengujian $\mathrm{R}^{2}$ Output untuk nilai $\mathrm{R}^{2}$ menggunakan aplikasi smartPLS 3.0 diperoleh pada Tabel 3 sebagai berikut:

Tabel 3. Inner Model (Uji R-Square)

\begin{tabular}{|l|l|l|}
\hline & R Square & Adjust R Square \\
\hline Kepuasan Pelanggan & 0.689 & 0.687 \\
\hline Citra Merek & 0.650 & 0.646 \\
\hline
\end{tabular}

Berdasarkan tabel diatas, Berdasarkan tabel diatas, menunjukan variabel Kepuasan pelanggan dengan nilai 0.689 artinya $0.689 \times 100=68.9 \%$ dan $100 \%-68.9 \%=31.1 \%$ atau 0.311. Hasil ini menunjukan bahwa variabel Kepuasan Pelanggan dipengaruhi oleh Persepsi Harga dan Kualitas Produk dengan nilai sebesar 68.9\% atau 0.689 yang dapat dinyatakan model kuat dikarenakan $>0.67$ serta terdapat sisanya dari $68.9 \%$ atau 0.689 yaitu $31.1 \%$ atau 0.311 yang kemungkinan dipengaruhi oleh variabel lain yang tidak dibahas dalam penelitian ini.

Namun yang kedua terdapat variabel Citra Merek dengan nilai 0.650 artinya $0.650 \mathrm{x}$ $100=65 \%$ dan $100 \%-65 \%=35 \%$ atau 0.35 Hasil ini menunjukan bahwa variabel Citra Merek dipengaruhi oleh Persepsi Harga dan Kualitas Produk dengan nilai sebesar $65 \%$ atau 0.650 yang dapat dinyatakan model moderate dikarenakan $>0,33$ serta terdapat sisanya dari $65 \%$ atau 0.650 yaitu $35 \%$ atau 0,35 yang kemungkinan dipengaruhi oleh variabel lain yang tidak dibahas dalam penelitian ini.

\section{Uji Q-Square $\left(\mathbf{Q}^{2}\right)$}

Uji Q Square merujuk pada nilai Goodness of Fit (GoF) Index, berdasarkan kriteria Nilai Stone Geisser $Q 2$. Jika nilai $Q$ Square berada di atas 0, maka dapat dikatakan model penelitian yang dibangun memiliki predictive relevance, sedangkan apabila nilai Q-square < 0 (nol), maka menunjukan bahwa model kurang memiliki predictive relevance (Ghozali, 2015).

Tabel 4. Inner Model (Q-square Predictive Relevance)

\begin{tabular}{cc}
\hline Variabel & $\mathbf{Q}^{2}$ \\
\hline Kepuasan Pelanggan & 0.383 \\
\hline Citra Merek & 0.401 \\
\hline
\end{tabular}


Berdasarkan pada data yang diolah dan disajikan, dapat di analisis bahwa terdapat nilai pada $\mathrm{Q}^{2}$ pada variabel Kepuasan Pelanggan sebesar 0.383 dan variabel Citra Merek sebesar 0.401 yang diukur dengan hasil pengukuran yang diolah menggunakan Smart PLS 3.0, diperoleh nilai Q-square sebagai berikut :

Q-Square $=1-\left(1-\mathrm{R}^{2}\right)$

$\mathrm{Q}^{2}$ Kepuasan Pelanggan :

$=1-(1-0,383)$

$=1-0,617$

$=0,383$

$\mathrm{Q}^{2}$ Citra Merek :

$=1-(1-0,401)$

$=1-0,599$

$=0,401$

Berdasarkan hasil perhitungan diatas, dapat diketahui nilai dari Q-square dari kepuasan pelanggan sebesar 0,383 0,345. Hasil tersebut menunjukan presentase dari penelitian ini yaitu sebesar 38,3\%. Sedangkan hasil 61,7\% lainnya berada diluar dari hasil penelitian ini. Hal tersebut dapat dinyatakan bahwa penelitian ini dapat dinyatakan telah memilki goodness of fit yang baik.

Namun selanjutnya Q-square dari citra merek hasil tersebut menunjukan presentase dari penelitian ini yaitu sebesar 40,1\%. Sedangkan hasil 59,9\% lainnya berada diluar dari hasil penelitian ini. Hal tersebut dapat dinyatakan bahwa penelitian ini dapat dinyatakan telah memilki goodness of fit yang baik.

Setelah melakukan pengujian tersebut, dilanjutkan dengan melakukan uji signifikan atau bootstrapping yang memberikan nilai signifikansi dari masing-masing indikator dari konstruk produk, persepsi harga, promosi maupun konstruk keputusan pembelian, yang dapat dilihat pada Gambar 2.

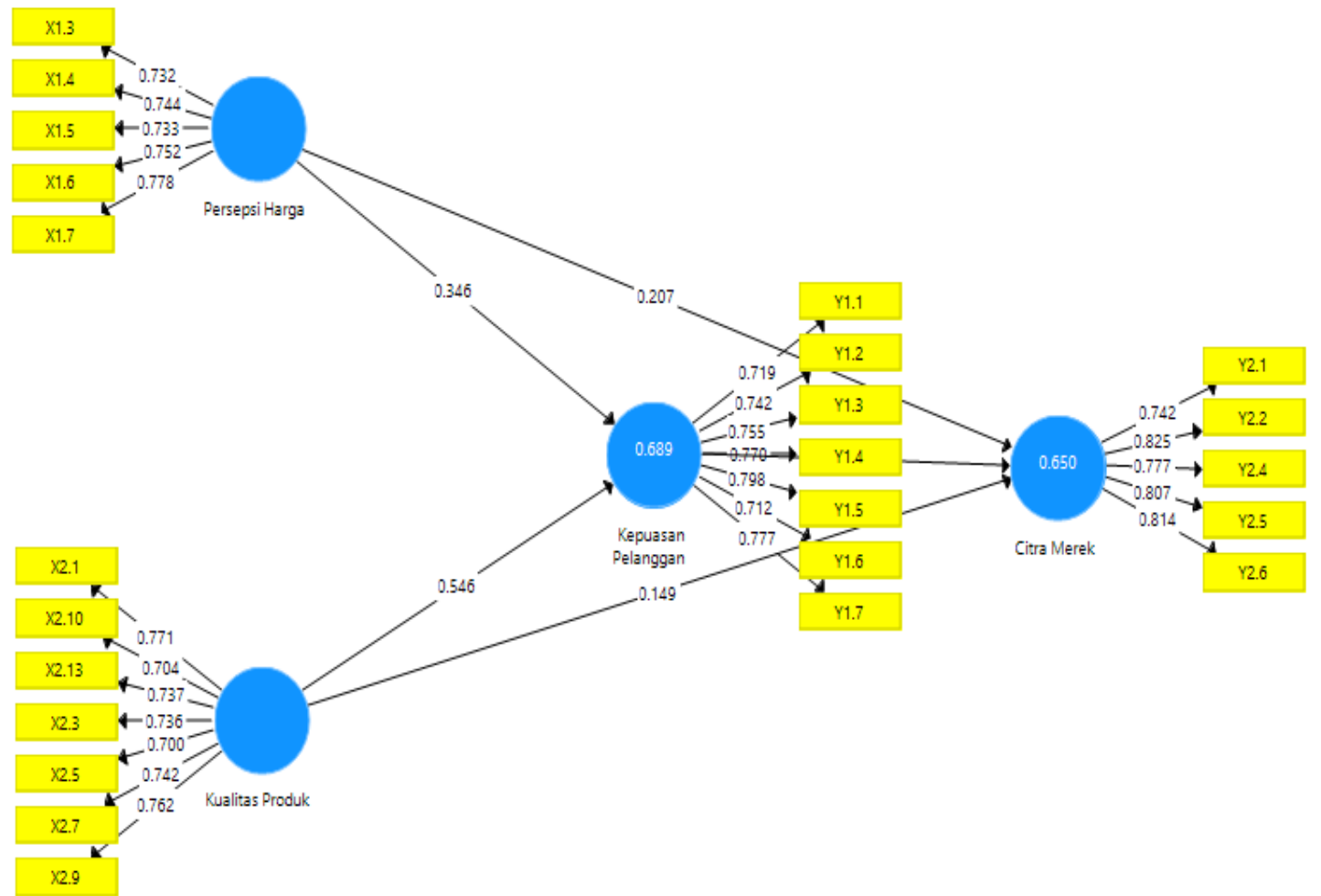

Gambar 2. Outer Model Persepsi Harga Dan Kualitas Produk Pengaruhnya Terhadap

Citra Merek Melalui Kepuasan Pelanggan 


\section{Analisis Hipotesis}

Pengujian hipotesis diuji dengan dasar hasil pengujian Inner Model yang meliputi output $r$-square, koefisien parameter dan Tstatistik. Untuk mengetahui apakah suatu hipotesis dapat diterima atau ditolak adalah dengan memperhatikan nilai signifikansi antar konstrak, Ttatistik, dan p-values. Rules of Thumb yang dipakai dalam penelitian ini adalah T-statistik >1.96. dengan tingkat signifikansi p-value $0.05(5 \%)$ dan koefisien beta bernilai positif dan signifikan.

\begin{tabular}{|l|c|c|c|c|}
\hline \multicolumn{1}{|c|}{ Tariabel } & $\begin{array}{c}\text { Tabel 5. Uji Hipotesis } \\
\text { Sampel } \\
\text { Asli }\end{array}$ & $\begin{array}{c}\text { Standar Deviasi } \\
\text { (STDEV) }\end{array}$ & T-Statistik & P-Value \\
\hline $\begin{array}{l}\text { Persepsi Harga -> Kepuasan } \\
\text { Pelanggan }\end{array}$ & 0.346 & 0.055 & 6.318 & 0.000 \\
$\begin{array}{l}\text { Kualitas Produk -> Kepuasan } \\
\text { Pelanggan }\end{array}$ & 0.546 & 0.055 & 9.890 & 0.000 \\
\hline $\begin{array}{l}\text { Persepsi Harga -> Citra } \\
\text { Merek }\end{array}$ & 0.207 & 0.069 & 2.890 & 0.003 \\
\hline $\begin{array}{l}\text { Kualitas Produk -> Citra } \\
\text { Merek }\end{array}$ & 0.149 & 0.073 & 2.029 & 0.043 \\
\hline $\begin{array}{l}\text { Kepuasan Pelanggan -> Citra } \\
\text { Merek }\end{array}$ & 0.513 & 0.082 & 6.004 & 0.000 \\
\hline
\end{tabular}

Hasil analisis SmartPLS terhadap hubungan variabel eksogen dan variabel endogen dipengaruhi oleh variabel intervening menunjukkan bahwa semua hipotesis sudah sesuai. Berikut penjelasan mengenai hasil uji hipotesis:

\section{Persepsi Harga Terhadap Kepuasan Pelanggan $\left(\mathbf{H}_{1}\right)$}

Hipotesis pertama menguji pengaruh langsung persepsi harga terhadap kepuasan pelanggan. Berdasarkan hasil penelitian didapatkan nilai koefisien persepsi harga terhadap kepuasan pelanggan sebesar 0.346 dan Tstatistik 6.318. Dari hasil tersebut dinyatakan bahwa Tstatistik berpengaruh signifikan karena $>1.96$ dengan p-value sebesar $0.000<0.05$ sehingga hipotesis pertama diterima. Dengan demikian dapat dinyatakan bahwa persepsi harga berpengaruh positif dan signifikan terhadap kepuasan pelanggan $\left(\mathbf{H}_{\mathbf{1}}\right.$ diterima).

\section{Kualitas Produk Terhadap Kepuasan Pelanggan $\left(\mathrm{H}_{2}\right)$}

Hipotesis pertama menguji pengaruh langsung kualitas produk terhadap kepuasan pelanggan. Berdasarkan hasil penelitian didapatkan nilai koefisien persepsi harga terhadap kepuasan pelanggan sebesar 0.546 dan Tstatistik 9.890. Dari hasil tersebut dinyatakan bahwa Tstatistik berpengaruh signifikan karena $>1.96$ dengan p-value sebesar $0.000<0.05$ sehingga hipotesis kedua diterima. Dengan demikian dapat dinyatakan bahwa kualitas produk berpengaruh positif dan signifikan terhadap kepuasan pelanggan $\left(\mathbf{H}_{2}\right.$ diterima).

\section{Persepsi Harga Terhadap Citra Merek $\left(\mathrm{H}_{3}\right)$}

Hipotesis ketiga menguji pengaruh langsung persepsi harga terhadap citra merek. Berdasarkan hasil penelitian didapatkan nilai koefisien persepsi harga terhadap kepuasan pelanggan sebesar 0.207 dan Tstatistik 2.890. Dari hasil tersebut dinyatakan bahwa Tstatistik berpengaruh signifikan karena $>1.96$ dengan p-value sebesar $0.003<0.05$ sehingga hipotesis ketiga diterima. Dengan demikian dapat dinyatakan bahwa persepsi harga berpengaruh positif dan signifikan terhadap citra merek $\left(\mathbf{H}_{3}\right.$ diterima). 


\section{Kualitas Produk Terhadap Citra Merek $\left(\mathbf{H}_{4}\right)$}

Hipotesis keempat menguji pengaruh langsung kualitas produk terhadap citra merek. Berdasarkan hasil penelitian didapatkan nilai koefisien persepsi harga terhadap kepuasan pelanggan sebesar 0.149 dan Tstatistik 2.029. Dari hasil tersebut dinyatakan bahwa Tstatistik berpengaruh signifikan karena $>1.96$ dengan p-value sebesar $0.043<0.05$ sehingga hipotesis keempat diterima. Dengan demikian dapat dinyatakan bahwa kualitas produk berpengaruh positif dan signifikan terhadap citra merek $\left(\mathbf{H}_{\mathbf{4}}\right.$ diterima $)$.

\section{Kepuasan Pelanggan Terhadap Citra Merek $\left(\mathbf{H}_{5}\right)$}

Hipotesis kelima menguji pengaruh langsung kepuasan pelanggan terhadap citra merek. Berdasarkan hasil penelitian didapatkan nilai koefisien persepsi harga terhadap kepuasan pelanggan sebesar 0.513 dan Tstatistik 6.004. Dari hasil tersebut dinyatakan bahwa Tstatistik berpengaruh signifikan karena $>1.96$ dengan p-value sebesar $0.000<0.05$ sehingga hipotesis kelima diterima. Dengan demikian dapat dinyatakan bahwa kepuasan pelanggan berpengaruh positif dan signifikan terhadap citra merek $\left(\mathbf{H}_{\mathbf{5}}\right.$ diterima).

\section{Analisis Mediasi}

Penelitian ini menggunakan uji mediasi dengan melihat hasil Output SmartPLS pada Bootstrapping bagian Specific Indirect Effects. Analisis mediasi digunakan untuk menguji variabel mediasi sebagai penghubung antara variabel bebas dan terikat ditunjukan dengan tabel 6.

Tabel 6. Hasil Mediasi (Specific Indirect Effect)

\begin{tabular}{lccccc}
\hline \multicolumn{1}{c}{ Variabel } & $\begin{array}{c}\text { Sampel } \\
\text { asli }\end{array}$ & $\begin{array}{c}\text { Standar } \\
\text { Deviasi } \\
\text { (STDEV) }\end{array}$ & T-Statistik & P-Value & Keterangan \\
\hline $\begin{array}{l}\text { Persepsi Harga } \\
\text { - Kepuasan }\end{array}$ & 0.178 & 0.040 & 4.416 & 0.000 & Full Mediation \\
$\begin{array}{l}\text { Pelanggan -> Citra } \\
\text { Merek }\end{array}$ & & & & & \\
\hline $\begin{array}{l}\text { Kualitas Produk -> } \\
\text { Kepuasan Pelanggan - } \\
>\text { Citra Merek }\end{array}$ & 0.280 & 0.058 & 4.817 & 0.000 & Full Mediation \\
\hline
\end{tabular}

\section{Kepuasan Pelanggan Memediasi Persepsi Harga Terhadap Citra Merek $\left(\mathrm{H}_{6}\right)$}

Hipotesis keenam menguji pengaruh tidak langsung persepsi harga terhadap citra merek melalui kepuasan pelanggan. Berdasarkan hasil penelitian didapatkan nilai koefisien persepsi harga terhadap citra merek melalui kepuasan pelanggan sebesar 0.176 dan nilai Tstatistik 4.416. dari hasil tersebut dinyatakan bahwa Tstatistik berpengaruh signifikan karena $>1.96$ dengan p-value $0.000<0.50$ sehingga hipotesis keenam diterima. Dengan demikian dapat dinyatakan bahwa kepuasan pelanggan memiliki peran yang berpengaruh positif dan signifikan serta terbukti mampu memediasi persepsi harga terhadap citra merek dan dinyatakan sebagai full mediation yang artinya menunjukan bahwa kepuasan pelanggan memediasi persepsi harga terhadap citra merek $\left(\mathbf{H}_{\mathbf{6}}\right.$ diterima).

\section{Kepuasan Pelanggan Memediasi Kualitas Produk Terhadap Citra Merek $\left(\mathbf{H}_{7}\right)$}

Hipotesis ketujuh menguji pengaruh tidak langsung kualitas produk terhadap citra merek melalui kepuasan pelanggan. Berdasarkan hasil penelitian didapatkan nilai koefisien kualitas produk terhadap citra merek melalui kepuasan pelanggan sebesar 0.280 dan nilai Tstatistik 4.817. dari hasil tersebut dinyatakan bahwa Tstatistik berpengaruh signifikan karena $>1.96$ dengan p-value $0.000<0.50$ sehingga hipotesis ketujuh diterima. Dengan 
demikian dapat dinyatakan bahwa kepuasan pelanggan memiliki peran yang berpengaruh positif dan signifikan serta terbukti mampu memediasi kualitas produk terhadap citra merek dan dinyatakan sebagai full mediation yang artinya menunjukan bahwa kepuasan pelanggan memediasi kualitas produk terhadap citra merek $\left(\mathbf{H}_{7}\right.$ diterima)

\section{KESIMPULAN}

Berdasarkan Hipotesis, hasil pengolahan data dan pembahasan, kesimpulan riset adalah adalah, sebagai berikut:

1. Persepsi harga berpengaruh positif dan signifikan terhadap kepuasan pelaggan. Hal ini menunjukan bahwa semakin baik persepsi harga produk Bear Brand maka semakin meningkat kepuasan pelanggan untuk melakukan pembeli produk Bear Brand di daerah kelurahan wanasari.

2. Kualitas produk berpengaruh positif dan signifikan terhadap kepuasan pelanggan. Hal ini menunjukan bahwa semakin baik kualitas produk Bear Brand maka semakin puas konsumen mengkonsumsi produk Bear Brand di daerah kelurahan wanasari.

3. Persepsi harga berpengaruh positif dan signifikan terhadap citra merek. Hal ini menunjukan bahwa semakin baik persepsi harga produk Bear Brand di pandangan masyarakat maka semakin baik pula citra merek Bear Brand dikalangan masyarakat di kelurahan wanasari.

4. Kualitas produk berpengaruh positif dan signifikan terhadap citra merek, Hal ini menunjukan bahwa baik kualitas produk Bear Brand dipandangan konsumen maka semakin baik pula citra merek Bear Brand dikalangan masyarakat di kelurahan wanasari.

5. Kepuasan pelanggan berpengaruh positif dan signifikan terhadap citra merek. Hal ini menunjukan bahwa semakin besar kepuasan pelanggan terhadap produk Bear Brand maka semakin baik pula citra merek Bear Brand dikalangan masyarakat di kelurahan wanasari.

6. Kepuasan pelanggan terbukti memediasi persepsi harga terhadap citra merek. Hal ini menunjukan bahwa semakin baik persepsi harga pada produk Bear Brand maka kepuasan konsumen juga semakin meningkat sehingga semakin baik pula citra merek Bear Brand di kalangan masyarakat kelurahan wanasari.

7. Kepuasan pelanggan terbukti memediasi kualitas produk terhadap citra merek. Hal ini menunjukan bahwa semakin baik kualitas produk Bear Brand maka kepuasan pelanggan juga semakin meningkat sehingga semakin baik pula citra merek Bear Brand di kalangan masyarakat kelurahan wanasari.

\section{DAFTAR RUJUKAN}

Afnina, A., \& Hastuti, Y. (2018). Pengaruh Kualitas Produk terhadap Kepuasan Pelanggan. Jurnal Samudra Ekonomi Dan Bisnis, 9(1), 21-30. https://doi.org/10.33059/jseb.v9i1.458

Agussalim M dan Hapzi Ali. (2017). Model Kepuasan Pelanggan: Analisis Kualitas Produk Dan Kualitas Layanan Terhadap Citra Merek Pada Giant Citra Raya Jakarta. Jurnal Manajemen, 21(3), 317. https://doi.org/10.24912/jm.v21i3.254

Ali, H. (2019). Building Repurchase Intention and Purchase Decision: Brand Awareness and Brand Loyalty Analysis (Case Study Private Label Product in Alfamidi Tangerang). Saudi Journal of Humanities and Social Sciences. https://doi.org/10.36348/sjhss.2019.v04i09.009

Ali, H., Evi, N., \& Nurmahdi, A. (2018). The Influence of Service Quality, Brand Image and Promotion on Purchase Decision at MCU Eka Hospital. Business and Management Studies. https://doi.org/10.21276/sjbms.2018.3.1.12

Ali, H., \& Mappesona, H. (2016). Build brand image: Analysis Service Quality and Product Quality (case study at Giant Citra Raya). International Journal of Economic Research. 
Ali, H., Narulita, E., \& Nurmahdi, A. (2018). Saudi Journal of Business and Management Studies ( SJBMS ) The Influence of Service Quality, Brand Image and Promotion on Purchase Decision at MCU Eka Hospital. Business and Management Studies, 6663, 8897. https://doi.org/10.21276/sjbms.2018.3.1.12

Andrian, W., \& Fadillah, A. (2021). Pengaruh Citra Merek, Pengalaman Merek, Dan Nilai Pelanggan Terhadap Kepuasan Pelanggan Airasia. Jurnal Ilmiah Pariwisata Kesatuan, 2(1), 53-60. https://doi.org/10.37641/jipkes.v2i1.586

Anggita, R., \& Ali, H. (2017a). The Influence of Product Quality, Service Quality and Price to Purchase Decision of SGM Bunda Milk. Scholars Bulletin. https://doi.org/10.21276/sb

Anggita, R., \& Ali, H. (2017b). The Influence of Product Quality, Service Quality and Price to Purchase Decision of SGM Bunda Milk (Study on PT. Sarihusada Generasi Mahardika Region Jakarta, South Tangerang District). Scholars Bulletin. https://doi.org/10.21276/sb

Anggita, R. H. A. (2017). The Influence of Product Quality, Service Quality and Price to Purchase Decision of SGM Bunda Milk. Scholars Bulletin. Journal, A Multidisciplinary, 239-244. https://doi.org/10.21276/sb

Ari Setiyaningrum, Jusuf Udaya, dan E. (2015). Prinsip-Prinsip Manajamen Pemasaran. Andi.

Arief Budiyanto. (2018). PENGARUH PERSEPSI HARGA, KUALITAS LAYANAN DAN BRAND IMAGE TERHADAP TINGKAT KEPUASAN KONSUMEN DI PT. YERRY PRIMATAMA HOSINDO. 1(3), 71-80.

Bayu Prawira Ni Nyoman Kerti. (2013). Pengaruh Kualitas Produk, Citra Merek dan Persepsi Harga terhadap Keputusan Pembelian Konsumen Produk Smartphone Samsung di Kota Denpasar,. Jurnal Ekonomi Dan Bisinis, Universitas Udayana, Bali Indonesia.

Binsar, J., Pangaribuan, M., \& Ali, H. (2018). Influence Service Quality, Customer Relationship and Customer Satisfaction to Customer Loyalty: Case Study in Individual Customer PT. Prudential in 2016. Saudi Journal of Business and Management Studies (SJBMS. https://doi.org/10.21276/sjbms.2018.3.4.7

Brata, B. H., Husani, S., \& Ali, H. (2017). The Importance of Quality Products, Price, Promotion, and Location to Product Purcese Decision on Nitchi At PT. Jaya Swarasa Agung in Central Jakarta. Saudi Journal of Business and Management Studies. https://doi.org/10.21276/sjbms

Desfiandi, A., Desfiandi, A., \& Ali, H. (2017). Composite Stock Price Index (IHSG) Macro Factor in Investment in Stock (Equity Funds). International Journal of Economics and Financial Issues.

Djojo, A., \& Ali, H. (2012). Information technology service performance and client's relationship to increase banking image and its influence on deposits customer banks loyalty (A survey of Banking in Jambi). In Archives Des Sciences.

Fandy Tjiptono. (2015). Strategi Pemasaran (Edisi 4). Andi Offset.

Hadita. (2017). Pengaruh Iklan dan Kualitas Pelayanan terhadap Kepuasan Pelanggan di Giant Cabang Kalibata.

Hadita. (2019). Promosi Dan Harga pada Kepuasan Pelanggan Restoran Fast Food. Ekspektra: Jurnal Bisnis Dan Manajemen, 3, 25-38. https://doi.org/10.25139/ekt.v3i1.1431

Hadita, H. (2020). The Impact of the First Media Product Purchase Decision on Brand Image and Product Quality (First Media Customer Survey in DKI Jakarta). American Journal of Humanities and Social ..., 4, 77-85. http://repository.ubharajaya.ac.id/8721/

Hadita, Widjanarko, W., \& Hafizah. (2020). Pengaruh Kualitas Produk Smartphone Terhadap Keputusan Pembelian di Masa Pandemic Covid19. Jurnal Kajian Ilmiah, 20(3), 261- 
268. https://doi.org/10.31599/jki.v20i3.294

Hairiyah, S., \& Ali, H. (2017). Customer Decision Analysis in Taking Multipurpose Loan : Promotions, Locations and Credit Procedures ( A Case of the Bank " PQR Jakarta "). Saudi Journal of Business and Management Studies. https://doi.org/10.21276/sjbms.2017.2.3.6

Hartadi, W. (2018). Analisis Pengaruh Persepsi Harga, Kualitas Produk Dan Citra Merek Terhadap Kepuasan Pelanggan Sepeda Motor Sport Yamaha Yzf-R25 Di Kota Cilegon. Journal Industrial Servicess, 4(1), 113-117. https://doi.org/10.36055/jiss.v4i1.4097

Hartanto, A., \& Andreani, F. (2019). Pengaruh Kualitas Produk, Kualitas Layanan, Dan Lingkungan Fisik Terhadap Loyalitas Pelanggan Melalui Kepuasan Pelanggan Sebagai Variabel Mediasi Di De Mandailing Cafe Surabaya. Agora, Vol 7, No(1), 1-6. http://publication.petra.ac.id

Hazimi Bimaruci Hazrati Havidz, M. R. M. (2020). BRAND IMAGE AND PURCHASING DECISION: ANALYSIS OF PRICE PERCEPTION AND PROMOTION(LITERATURE REVIEW OF MARKETING MANAGEMENT). 1(2), 358-372. https://doi.org/10.38035/DIJEFA

Ibrahim, M., \& Thawil, S. M. (2019). Pengaruh Kualitas Produk Dan Kualitas Pelayanan Terhadap Kepuasan Konsumen. Jurnal Riset Manajemen Dan Bisnis (JRMB) Fakultas Ekonomi UNIAT, 4(1), 175-182. https://doi.org/10.36226/jrmb.v4i1.251

Ikhsani, K., \& Ali, D. H. (2017). Keputusan Pembelian: Analisis Kualitas Produk, Harga dan Brand Awareness (Studi Kasus Produk Teh Botol Sosro di Giant Mall Permata Tangerang). In Jurnal SWOT.

Ilhamalimy, R. R., \& Mahaputra, M. R. (2021). Pengaruh Kualitas Pelayanan Dan Kualitas Produk Terhadap Keputusan Pembelian Dan Kepuasan Pelanggan (Literature Review Manajemen Pemasaran). 1(1), 85-97.

Imron, I. (2019). Analisa Pengaruh Kualitas Produk Terhadap Kepuasan Konsumen Menggunakan Metode Kuantitatif Pada CV. Meubele Berkah Tangerang. Indonesian Journal on Software Engineering (IJSE), 5(1), 19-28. https://doi.org/10.31294/ijse.v5i1.5861

Irwanty L Situmorang. (2017). Pengaruh Kualitas Produk dan Iklan terhadap Citra Merek dan Keputusan Pembelian Produk Kecantikan Merek Pond's pada Remaja di Kota Pekanbaru. Jurnal Online Mahasiswa Fakultas Ekonomi Universitas Riau, 4(1), 72-86.

Journal, A. M., \& Ali, H. (2017). Scholars Bulletin Analysis of the Company Image and Service Quality through Customer Satisfaction to Customer Loyalty ( A Field Research in PT . Nusantara Water Centre ). 149-158. https://doi.org/10.21276/sb.2017.3.3.10

Kotler, P., \& Keller, K. L. (2012). Marketing Management (14th ed.). Harlow: Pearson Education.

Kotler, P. \& Keller, K. L. (2012). Manajemen Pemasaran (Jilid 1 Ed). Erlangga.

Kotler dan Keller. (2012). Manajemen Pemasaran (jiid 1).

Kotler, P. dan K. L. K. (2016). Marketing Managemen (I. Pearson Education (ed.); 15th Editi). PT Index. kelompok Gramedia.

Limakrisna, N., \& Ali, H. (2016). Model of Customer Satisfaction: Empirical Study At Fast Food Restaurants in Bandung. International Journal of Business and Commerce, 5(06), 132-146. www.ijbcnet.com

Mappesona, H., Ikhsani, K., \& Ali, H. (2020). Customer purchase decision model, supply chain management and customer satisfaction: Product quality and promotion analysis. International Journal of Supply Chain Management.

Meutia, K. I., Hadita, \& Widjarnarko, W. (2021). Dampak Brand Image dan Harga terhadap Keputusan Pembelian Produk Miniso. Journal of Technopreneurship on Economics and Business Review, 2(2), 75-87. https://doi.org/10.37195/jtebr.v2i2.68 
Mira, S. dan. (2018). Pengaruh Citra Merek Dan Kualitas Pelayanan Terhadap Kepuasan Nasabah Pt Pegadaian (Persero) Batam. JIM UPB (Jurnal Ilmiah Manajemen Universitas Putera Batam), 6(2), 86. https://doi.org/10.33884/jimupb.v6i2.682

Moh. Budi Darma, Sulaiman Effendi, A. A. T. J. (2018). Pengaruh citra merek dan kepuasan pelanggan terhadap loyalitas pelanggan kosmetik. Efek Kecerdasan Emosional Terhadap Kinerja Karyawan: Dimediasi Stres Kerja Dan Dimoderasi Religiusits, Volume 2(1), 1-8. https://doi.org/10.5281/zenodo.1236827

Nastiti, A., \& Astuti, S. R. T. (2019). Pengaruh Persepsi Harga, Kualitas Layanan dan Citra Merek terhadap Kepuasan Pelanggan dan Dampaknya terhadap Loyalitas Pelanggan Taksi New Atlas di Kota Semarang. Diponegoro Journal of Management, 8(1), 126136.

Noerchoidah. (2013). Analisis Pengaruh Harga , Kualitas Produk Dan Iklan Terhadap Brand Image Dan Keputusan Pembelian Sepeda Motor Merek Kawasaki. Wiga, 3(1), 48-60.

Novansa, H., \& Ali, H. (1926). Purchase Decision Model: Analysis of Brand Image, Brand Awareness and Price (Case Study SMECO Indonesia SME products). Saudi Journal of Humanities and Social Sciences. https://doi.org/10.21276/sjhss

Nugraha, S. S. (2017). MENINGKATKAN MINAT MENGGUNAKAN GO-JEK ( Studi Pada GO-JEK Di Kota Semarang ).

Paris, Y., \& dan Deli Rahmawati. (2020). PENGARUH PERSEPSI HARGA TERHADAP KEPUASAN KONSUMEN PENGGUNA JASA TRAVEL. GIS Business, Volume 3 $N(6), 121-27$. https://doi.org/10.26643/gis.v14i6.18868

Prihartono, \& Ali, H. (2020). The promises ethics and marketing concept strategy as a competitive advantage on private higher education (A survey on perception of product attributes and promotion mix in Indonesia). Talent Development and Excellence.

Primus Makarius Jebarum. (2019). Pengaruh Harga,Kualitas Produk Dan Citra Merek Terhadap Loyalitas Konsumen Dengan Kepuasan Konsumen Sebagai Variabel Mediasi (Studi kasus konsumen sepatu futsal specs di Yogyakarta). http://repository.usd.ac.id/35732/2/152214037_full.pdf

Putra, R. (2021). Determinasi Kepuasan Pelanggan Dan Loyalitas Pelanggan Terhadap Kualitas Produk, Citra Merek Dan Persepsi Harga (Literature Review Manajemen Pemasaran). Jurnal Ekonomi Manajemen Sistem Informasi, 2(4), 516-524. https://doi.org/10.31933/jemsi.v2i4.461

Rafael Billy Leksono dan Herwin. (2017). PENGARUH HARGA DAN PROMOSI GRAB TERHADAP BRAND IMAGE YANG MEMPENGARUHI KEPUTUSAN PEMBELIAN KONSUMEN PENGGUNA TRANSPORTASI BERBASIS ONLINE. Jurnal Riset Manajemen Dan Bisnis, 2(3), 381-390.

Rangga, A., \& Nalendra, A. (2018). PENGARUH KUALITAS PELAYANAN HARGA KEPUASAN PELANGGAN TERHADAP LOYALITAS PELANGGAN (STUDI KASUS PELANGGAN IM3 MADIUN). 3(2), 281-288.

Richardo, Hussin, M., Bin Norman, M. H., \& Ali, H. (2020). A student loyalty model: Promotion, products, and registration decision analysis-Case study of griya english fun learning at the tutoring institute in wonosobo central Java. International Journal of Innovation, Creativity and Change.

Rispita dan Khasanah, I. (2019). ANALISIS PENGARUH KUALITAS PRODUK, PERSEPSI HARGA DAN DESAIN PRODUK TERHADAP CITRA MEREK DAN KEPUTUSAN PEMBELIAN (Studi pada konsumen kosmetik Pixy di Semarang). Management Analysis Journal. https://repofeb.undip.ac.id/102/

Riyanto, A. (2018). Implikasi Kualitas Pelayanan Dalam Meningkatkan Kepuasan Pelanggan Pada PDAM Cibadak Sukabumi. Ecodemica, 2(1), 117-124. https://ejournal.bsi.ac.id/ejurnal/index.php/ecodemica/article/view/2911/pdf 
Ruth Amryyanti, I. P. G. S., \& dan Cahya, K. N. (2013). PENGARUH KUALITAS LAYANAN, PRODUK, DAN KEWAJARAN HARGA TERHADAP KEPUASAN DAN LOYALITAS PELANGGAN PADA LnC SKIN CARE SINGARAJA. 02(01), 22-29. https://ojs.unud.ac.id/index.php/EEB/article/view/4371

Sangadji, E.M., dan S. (2013). Prilaku Konsumen: Pendekatan Praktis Disertai:Himpunan Jurnal Penelitian. Penerbit Andi.

Savitri, I. A. P. D., \& Wardana, I. M. (2018). Pengaruh Citra Merek, Kualitas Produk Dan Persepsi Harga Terhadap Kepuasan Dan Niat Beli Ulang. E-Jurnal Manajemen Universitas Udayana, 7(10), 5748. https://doi.org/10.24843/ejmunud.2018.v07.i10.p19

Schiffman, L. G. \& Wisenblit, J. L. (2015). Consumer Behavior (Edisi 11 G). Pearson Education Limited.

Septeri, A. (2018). PENGARUH KUALITAS PRODUK DAN HARGA TERHADAP CITRA MEREK SERTA IMPLIKASINYA TERHADAP KEPUTUSAN PEMBELIAN PRODUK BLOODS INDUSTRIES DI KOTA BANDUNG.

Setyadi, D. A. (2017). Build Customer Loyalty with CRM and Brand Image (Case Study on Giant Citra Raya). IOSR Journal of Business and Management, 19(01), 35-42. https://doi.org/10.9790/487x-1901043542

Setyo, P. E. (2017). Pengaruh Kualitas Produk Dan Harga Terhadap Kepuasan Konsumen "Best Autoworks." PERFORMA: Jurnal Manajemen Dan Start-Up Bisnis, 1(6), 755764.

Setyowati, E. (2016). Pengaruh Kualitas Pelayanan, Harga, Dan Citra Merek Terhadap Loyalitas Pelanggan Dengan Kepuasan Pelanggan Sebagai Variabel Pemediasi. Jurnal Manajemen Dayasaing, 18(2), 102. https://doi.org/10.23917/dayasaing.v18i2.4507

Shihab, N. C. M. S. (2018). PENGARUH PERSEPSI HARGA, KUALITAS PRODUK, CITRA MEREK DAN LAYANAN PURNA JUAL TERHADAP KEPUTUSAN PEMBELIAN DAN DAMPAKNYA TERHADAP KEPUASAN PELANGGAN SMARTPHONE ASUS STUDI KASUS DI PT.DATASCRIP. Jemi, 1(01), 34-46.

Suarjana, I. K., \& Suprapti, N. W. S. (2018). Pengaruh Persepsi Harga, Pengetahuan Produk, Dan Citra Perusahaan Terhadap Niat Beli Layanan Multi Servis Merek Indihome. EJurnal Manajemen Universitas Udayana, 7(4), 251833. https://doi.org/10.24843/EJMUNUD.2018.v07.i04.p08

Suastini, I. A. K. S., \& Mandala, K. (2018). Pengaruh Persepsi Harga, Promosi Penjualan, Dan Citra Merek Terhadap Kepuasan Untuk Meningkatkan Loyalitas Pelanggan. EJurnal Manajemen Universitas Udayana, $\quad 8(1), \quad 84$. https://doi.org/10.24843/ejmunud.2019.v08.i01.p04

Sulistiorini, M. S., \& Ali, H. (2017). Customer satisfaction model: Product analysis, price, promotion and distribution (case study at PT Integrasia Utama). International Journal of Applied Business and Economic Research.

Thanh Nguyen, P., Ali, H., \& Agung Hudaya. (2019). MODEL BUYING DECISION AND REPEAT PURCHASE: PRODUCT QUALITY ANALYSIS (Case Study of Bank Permata Syariah Jakarta KPR Financing Customers). Dinasti International Journal of Management Science. https://doi.org/10.31933/dijms.v1i1.29

Tjiptono. (2019). Strategi Pemasaran Prinsip \& Penerapan (Edisi 1). Andi.

Tjiptono, F. (2014). Service, Quality \& Satisfaction (Edisi 3). Andi.

Toto Handiman, U., \& Ali, H. (2019). The Influence of Brand Knowledge and Brand Relationship On Purchase Decision Through Brand Attachment. In International Journal of Business Marketing and Management (IJBMM).

W, G. G. T., \& E. P., \& Nuralam, I. P. (2018). PENGARUH CITRA MEREK, KUALITAS LAYANAN, DAN HARGA TERHADAP KEPUASAN PELANGGAN GO-RIDE. 61(2), $118-126$. 
Wicaksono, P. U., \& Mudiantono. (2017). Analisis Pengaruh Kualitas Produk, Persepsi Harga, Promosi Terhadap Citra Merek Dan Minat Beli Serta Dampaknya Pada Keputusan Pembelian Kartu Perdana Xl Axiata Di Semarang. Diponegoro Journal Ofmanagement, 6(2), 1-11.

Widayati, C.C., Ali, H., Permana, D., \& Nugroho, A. (2020). The role of destination image on visiting decisions through word of mouth in urban tourism in Yogyakarta. International Journal of Innovation, Creativity and Change, 12(3).

Widayati, Christina Catur, Ali, H., Permana, D., \& Nugroho, A. (2020). The role of destination image on visiting decisions through word of mouth in urban tourism in Yogyakarta. International Journal of Innovation, Creativity and Change.

Wifky Muharam dan Euis Soliha. (2017). Keputusan Pembelian Konsumen Honda Mobilio. Kualitas Produk, Citra Merek, Persepsi Harga Dan Keputusan Pembelian Konsumen Honda Mobilio, 2014, 755-762.

Wydyanto, A. Y. (2020). Model citra merek dan pembelian: persepsi harga dan kualitas produk (tinjauan pustaka pemasaran pengelolaan). 1, 275-285. https://doi.org/10.31933/JAFM

Wydyanto, W., \& Rafqi Ilhamalimy, R. (2021). Determination of Purchasing Decisions and Customer Satisfaction: Analysis of Service Quality and Product Quality (Marketing Management Literature Review). Dinasti International Journal of Education Management And Social Science, 2(3), 565-575. https://doi.org/10.31933/dijemss.v2i3.822

Yunita, D., \& Ali, H. (2017). Model of Purchasing Decision ( Renting ) of Generator Set: Analysis of Product Quality, Price an Service at PT . Hartekprima Listrindo. Economics, Business and Management. https://doi.org/10.21276/sjebm.2017.4.11.12 